This is an Accepted Manuscript of an article published by Taylor \& Francis in INTERNATIONAL REVIEW OF APPLIED ECONOMICS on 8 January 2014, available online:

http://www.tandfonline.com/10.1080/02692171.2013.858667 


\title{
The financial fragility and the crisis of the Greek government sector
}

\author{
Georgios Argitis ${ }^{\mathrm{a}, *}$ and Maria Nikolaidi ${ }^{\mathrm{b}}$
}

${ }^{a}$ Department of Economics, University of Athens, 8 Pesmatzoglou str, 10559 Athens, Greece; ${ }^{b}$ Labour Institute, Greek General Confederation of Labour, and Department of Economics, University of Athens, 71A Emmanouil Benaki str, 10681, Athens, Greece

The purpose of this paper is to develop Minskyan financial fragility indices for the government sector and to examine the financial structure of the Greek government before and after the onset of the sovereign debt crisis in 2009. We provide empirical evidence that clearly shows the growing financial fragility of the Greek public sector in the 2000's. We also assess the effectiveness of the implemented bailout adjustment programmes in Greece and claim that the conducted austerity measures and fiscal consolidation have not significantly improved the financial posture of the Greek government sector. We argue that the implementation of fiscal and wage austerity in an economy that lacks structural competitiveness produces prolonged recession and unemployment with adverse feedback effects on the financial fragility of the government.

Keywords: Minsky’s financial fragility; government sector; Greek debt crisis

JEL Classifications: E12, E60, H60

*Corresponding author. Email: gargeitis@econ.uoa.gr

Acknowledgements: We would like to thank the editor of this journal, Dimitri Papadimitriou, Eric Tymoigne and an anonymous referee for their constructive comments and suggestions. A preliminary version of this paper was presented at the 15th Conference of the Research Network Macroeconomics and Macroeconomic Policies (FMM), Berlin, October 28-29, 2011. The usual disclaimers apply. Maria Nikolaidi gratefully acknowledges the financial support from the European Union (European Social Fund - ESF) and Greek national funds through the Operational Program 'Education and Lifelong Learning' of the National Strategic Reference Framework (NSRF) - Research Funding Program: Heracleitus II. Investing in knowledge society through the European Social Fund. She also acknowledges the partial financial support from the Antonios Papadakis Endowment. 


\section{The financial fragility and the crisis of the Greek government sector}

\section{Introduction}

The current sovereign debt crisis in Greece, as well as the banking and fiscal instability in other Eurozone countries, brings forward the analytical and practical importance of Hyman Minsky’s ‘financial macroeconomics'. Minsky’s (1982; [1986] 2008) major concern was to point out that in monetary production economies instability is endogenous, because investment and capital development tend to rely on fragile financial structures. His 'financial instability hypothesis' examines the way in which economic units, primarily business firms and banks, create assets and liabilities and endogenously influence the cyclical and secular movements in the financial fragility of modern capitalist economies (see e.g. Fazzari and Papadimitriou 1992; Bellofiore and Ferri 2001; Papadimitriou and Wray 2010).

In spite of the fact that Minsky's theoretical framework basically examines the financial fragility of the private sector, his arguments can be extended to incorporate the financial fragility of the government sector (see Ferrari-Filho, Terra, and Conceição 2010). Minsky has argued in favour of the significance of his well-known hedge, speculative and Ponzi finance regimes for the government sector (see e.g. Minsky 1982, 32-33; 1992, 28). However, his argumentation has largely concentrated on sovereign countries in which the government sector appears to be a potential source of financial stability. He has not explicitly considered the case of nonsovereign countries in which the government sector might be a potential source of financial instability. Lemmen and Goodhart (1999), Sawyer (2001), Bell (2003), 
Wray (2003), Sardoni and Wray (2006) and Kelton and Wray (2009) have pointed out that the financial posture of the government sector of non-sovereign countries matters, because these countries cannot finance their expenditures and debt obligations by issuing their own currency. They have also argued that within the current institutional structure of the Eurozone the non-sovereign government spending depends on the perceived credit risk of government bonds in the financial markets. If this risk is conceived to be high, then the financing of government expenditures and debt commitments can be disrupted. ${ }^{1}$

Moreover, the institutional framework of the European Central Bank (ECB) which does not authorise the latter to function as 'lender of last resort' to the government sector of the Eurozone countries is the major reason that their sovereign bonds in the global financial markets face default risk. ${ }^{2}$ Government bond markets can discipline the countries with high and rising budget deficits, as exemplified by credit downgrades that place upward pressures on the lending interest rates and the prices of the Credit Default Swaps (CDSs). As long as the ECB does not guarantee the nondefault of the euro states, the debt-financing of the government deficits is susceptible to financial perceptions, the judgments of credit rating agencies and the speculation of investors, especially when these deficits are higher than the percentage defined by the Maastricht Treaty. ${ }^{3}$

Consequently, the financial posture of the national government sectors in the Eurozone has become of paramount importance for the analysis and evaluation of economies' financial stability and possibility of default. As the recent sovereign debt crisis has indicated, a government sector with increasing financing needs is 
susceptible to potential changes in financial perceptions. The latter may lead to its incapability to borrow, with devastating effects on the implementation of fiscal policy as well as on the financial and macroeconomic stability.

The purpose of this paper is to develop a Minskyan framework for the measurement of the government sector's financial fragility and to apply this framework in the case of Greece. The paper is organised as follows. In Section 2 we develop and propose various indices that enable us to measure the financial fragility of a government that has relinquished its monetary independence. In Section 3, we estimate the proposed indices for the Greek government sector prior and after the onset of the sovereign debt crisis. We also discuss the ineffectiveness of the implemented austerity policies over the period 2010-2012, showing that they have not significantly improved government sector's financial structure. Section 4 summarises and concludes.

\section{Measuring the financial fragility of a non-sovereign government sector}

At the epicentre of Minsky's analysis of financial fragility is his insight that 'borrowing and lending take place on the basis of margins of safety' (Minsky 1982, 74; see also Kregel 2008). The fundamental margin of safety is, according to Minsky, the excess of the expected cash inflows over the expected cash outflows. For a nonsovereign government sector, this margin of safety is given by the excess of the expected inflows from taxation, social contributions, asset ownership, asset liquidation or other sources, over the sum of the expected primary expenditures and the debt commitments (interest and principal repayment). 
The higher the expected cash inflows relative to the expected cash outflows the higher the margin of safety of the government sector. If the expected cash inflows fall short of the expected cash outflows, refinancing is necessary. The willingness of both the government and its lenders to engage into financial relationships that rely on refinancing is a function of financial markets' institutional structure and country's previous fiscal and growth performance. Furthermore, this willingness depends upon government's and borrowers' perception of the appropriate margin of safety and the conceived assuredness of future cash inflows.

We have already remarked in the introductory section that in the Eurozone in which the ECB does not act as 'lender of last resort' to the governments, the government sector can be financially fragile and, hence, a potential source of financial and macroeconomic instability. Therefore, the assessment of the financial structure of the government sector is crucial for the evaluation of the economic system's financial fragility. Drawing on Minsky's analytical framework, we argue that two factors should be taken into consideration in the measurement of the financial fragility of a non-sovereign government sector. First, government's income statement and balance sheet structure from which we can figure out the degree of government's reliance on the well functioning of the financial markets for honouring its debt commitments. Second, the extent to which the roll-over of government's debt relies upon financial markets' attitudes that can easily change as a result of small expectation shocks. In this context, we propose five indices to measure the financial fragility of a nonsovereign government: (1) the liquidity index, (2) the debt maturity index, (3) the liquid assets to debt ratio, (4) the shares to debt ratio and (5) the non-resident debt index. We proceed to present these indices in turn. 
(1) The liquidity index is based on Minsky's well-known taxonomy of hedge, speculative and Ponzi finance regimes. Extending Minsky's taxonomy, the government sector can be categorised into four regimes according to the relation between cash inflows, primary government expenditures and debt commitments. ${ }^{4}$ Note that in the constructed index cash inflows refer only to the revenues from the main operations of the government. Thus, they do not include inflows from liquid financial assets or from the sale of less liquid financial assets (the role of these inflows is captured by the liquid assets to debt ratio and the shares to debt ratio; see below).

The first finance regime is the hedge one, in which government is capable of covering all its debt commitments from its primary surplus. Algebraically, it holds that:

$T R-T E \geq I N T+A M O R T$

where $T R$ denotes the total government revenues, $T E$ stands for the total primary government expenditures, AMORT symbolises the amortisation of debt and INT denotes the interest payments. The hedge finance regime reflects the case in which there is sufficient liquidity to ensure the repayment of the debt obligations without new borrowing.

The second case is that of a speculative government, which can repay its interest without resorting to new borrowing. However, its primary surplus is not enough to cover the principal repayment. The speculative finance regime is characterised by the following relationship: 
Government's finance regime is Ponzi when the primary surplus is not enough to cover its interest payments. The relationship between the cash flows of a Ponzi finance regime is expressed as:

$0 \leq T R-T E<I N T$

Finally, when the government sector exhibits an ultra-Ponzi finance regime, it runs a primary deficit. This implies that a part of government's primary expenditures cannot be covered without new borrowing. The margins of safety are, therefore, at their lowest level. Algebraically, it holds that:

$T R-T E<0$

Several important points are in order. First, each of the above-mentioned finance regimes generates certain dynamics in the government's debt and financial commitments. In particular, if the government's finance regime is characterised as Ponzi or ultra-Ponzi, the net debt increases (assuming no changes in asset prices and exchange rates). ${ }^{5}$ Since a higher net debt implies more debt commitments and less financial assets in the future, the more a government remains in the Ponzi or ultraPonzi regime, the more difficult it is to improve its liquidity position. This may give rise to problems of debt sustainability, insolvency and loss of credibility. On the 
contrary, if the government is hedge or speculative its net debt declines. Thus, the risks of illiquidity and insolvency are lower.

However, it should be remarked that the link between the finance regimes and the gross debt to GDP dynamics is not straightforward. The government sector may be for many years in the ultra-Ponzi regime without seeing an explosion in its debt to GDP ratio. This is more likely to be the case when government expenditures have a significant growth-enhancing effect and the real (after-tax) lending interest rate is low relative to the real growth rate of the economy. On the other hand, the government sector may run a primary surplus that proves insufficient to prevent a rise in its debt to GDP ratio due to the existence of a much higher real (after-tax) lending interest rate than the real growth rate of the economy.

Second, the ability of a government to attain and sustain a sufficiently large budget surplus depends on various macroeconomic factors, which may not be directly controlled by itself. According to the 'financial balances approach' (Wray 2006, 2012; Godley et al. 2007; Kregel 2011; Sawyer 2011; Semieniuk, van Treeck, and Truger 2011; Zezza 2012), the financial position of the government is by definition a function of the balances of the private and the foreign sector of the economy. ${ }^{6}$ The fiscal balance can improve only if there is a deterioration in the balance of the private sector and/or in the balance of the foreign sector. Thus, a rise in private sector expenditures and/or a rise in exports can improve, everything else given, the fiscal balance without any change in the behaviour of fiscal authorities. On the contrary, cuts in government expenditures may not be effective in reducing a fiscal deficit to a target level if the expenditures of the private and the foreign sector do not increase enough to counter 
the contractionary effects of these cuts. In this case, the output is adversely affected and the automatic stabilisers may prevent the attainment of the intended balance. Similarly, a rise in tax rates may have, under certain circumstances, important detrimental effects on output and tax evasion, leading to lower rather than to higher tax revenues. ${ }^{7}$

Furthermore, the sustainability of the private sector's financial position is of paramount importance. Since government has a prominent role to play in stabilising the macroeconomy, a highly fragile private sector increases the possibility of unexpected government interventions (e.g. bank bailouts) which can substantially deteriorate the financial posture of the public sector. Moreover, if the tax revenues from various Ponzi activities of the private sector are significant, the financial position of the government sector can rapidly deteriorate as a result of financial or other shocks that dampen these activities.

Third, Ponzi and ultra-Ponzi governments might need to take further initiatives to create the liquidity that restores their solvency and credibility. For instance, if there are credit constraints, then the sustainability of a Ponzi, and especially, of an ultraPonzi government sector might require debt restructuring, complement to adequate macroeconomic and fiscal policies. ${ }^{8}$ Without debt restructuring, the restoration of a viable financial structure might not be possible. Besides, without debt restructuring money managers and bond holders are likely to speculate on country's default, triggering higher interest rates. 
Employing the classification among the four finance regimes, the following liquidity index $(L I)$ is constructed and proposed:

$$
L I=\left\{\begin{array}{cl}
\frac{T R-T E-I N T}{A M O R T}, & \text { if } T R-T E \geq I N T \\
\frac{T R}{T E+I N T+A M O R T}-1, & \text { if } 0 \leq T R-T E<I N T \\
\frac{T R}{T E+I N T+A M O R T}-2, & \text { if } \quad T R-T E<0
\end{array}\right.
$$

The financial fragility of the government increases as the liquidity index becomes lower. The government is: (i) hedge when the index is higher than 1; (ii) speculative when the index takes values between 0 and 1; (iii) Ponzi when the index lies between -1 and 0 ; and (iv) ultra-Ponzi when the index takes values between -2 and $-1 .{ }^{9}$

Our proposed liquidity index improves and extends the index suggested by FerrariFilho, Terra, and Conceição (2010) along the following lines. ${ }^{10}$ First, in the index proposed by Ferrari-Filho, Terra, and Conceição (2010), when $T R-T E<0$, the financial fragility of the government turns out to increase as the sum of interest and amortisation $(I N T+A M O R T)$ becomes smaller. This seems counterintuitive since an increase in debt commitments of the government decreases, ceteris paribus, its liquidity. On the contrary, when our index takes negative values, it becomes more negative as the debt commitments increase. Second, and more importantly, when the primary budget surplus does not cover the sum of interest and amortisation, the index 
proposed by Ferrari-Filho, Terra, and Conceição (2010) does not distinguish between a regime in which the government can cover its interest payments and a regime in which the government needs new debt to repay its interest. In our index, when the primary budget surplus does not cover the debt commitments, there are two cases: first, the case in which the index takes values between 0 and $l$ which implies that the government can cover its interest payments (speculative government), and, second, the case in which the index takes values between -1 and 0 which implies that the government cannot cover its interest payments (Ponzi government).

It should be pointed out that the government's liquidity index provides accurate information only about the past and the present situation of the government's financial structure. The estimation of the future values of the liquidity index requires projections over the government's primary balance and its debt commitments. Both variables are dynamic and depend on prior knowledge about many other monetary, fiscal and macroeconomic variables.

(2) The debt maturity index is defined as the ratio of long-term (higher than 5 years) debt to total debt. This index provides a general picture of the time profile of the government's principal repayment commitments. Minsky has pointed out the importance of debt maturity in the determination of the financial posture of an economic unit (see, e.g. Minsky [1986] 2008, 351-352). The higher the maturity the longer the horizon over which a specific debt must be repaid and, therefore, the lower the debt commitments in the short run. However, the relationship of the debt maturity index with the government's financial fragility is not straightforward. If the deficit of a government is expected to be higher in the short run rather than in the long run, a 
longer maturity is beneficial for the government's financial position. When the opposite holds, a longer maturity might lead to higher financial pressure in the long run. Government's financial fragility depends, therefore, on the decisions of the fiscal authorities about the 'optimal' combination of long-term and short-term debt. These decisions should rely not only on the expected fiscal balance but also on the expected conditions in the financial markets. However, irrespective of the expectations, it could be asserted that policy makers should keep a relatively small amount of the government debt in the form of short-term liabilities. This prevents continuous refinancing from the markets. At the same time, though, they should avoid deferring the majority of the debt repayments in the future. ${ }^{11}$

(3) The liquid assets to debt ratio is defined as the proportion of government's currency and deposits to its gross debt. In general, the higher the liquid assets held by economic units (relative to their debt) the easier it is to deal with unforeseen contingencies related to the fulfillment of their financial obligations (see, e.g. Minsky [1986] 2008, 90; Tymoigne 2009, 133). For the government, a high liquid assets to debt ratio implies that it can more easily use available cash in periods in which revenues and external finance availability might not be enough to cover expenditures and debt commitments.

(4) The shares to debt ratio is given by the value of the shares and other equity of the government relative to its gross debt. This index shows the extent to which the sale of financial assets can be used through privatisation for the reduction of the government debt and the fulfillment of government's financial commitments. Some issues should be pointed out. First, this index is sensitive to changes in the market price of 
government's shares. Euphoric financial conditions are broadly conducive to higher market prices and thus to higher proceeds from privatisations. Contrariwise, in periods of financial distress the market prices of government's shares are more likely to decline, reducing the proceeds from privatisations. Second, the positive cash inflows effects from privatisations in the short run do not necessarily compensate for the foregone revenues due to the sale of the related financial assets (e.g. dividends). Consequently, the long-run effect of privatisations on the government's financial position cannot be specified a priori. ${ }^{12}$

(5) The non-resident debt index is defined as the proportion of government debt held by non-residents. Arguably, non-residents are less willing to continue refinancing, especially when the level of the government debt is high (see e.g. Bank of Italy 2011, 14; Broos and de Haan 2012). Thus, the higher the non-resident to total debt ratio the higher, ceteris paribus, the possibility of financial constraints in the case of adverse expectation shocks. It is also noteworthy that when the non-resident debt is high, a significant proportion of the interest payments paid on government's outstanding debt accrues to foreigners, and thus does not contribute to the income of the domestic private sector. This has negative effects on the domestic aggregate demand (see Zezza 2012).

\section{The financial fragility of the Greek government sector}

\subsection{The pre-crisis period}

Figure 1 displays the liquidity index for the Greek government sector over the period 1988-2012. ${ }^{13}$ We observe that before 2001 the Greek government was either in the 
Ponzi or in the ultra-Ponzi regimes. More precisely, the Greek government was ultraPonzi in the 1988-1993 time span and Ponzi over the period 1994-2000. This implies that in the pre-EMU period there was a significant accumulation of debt commitments. Arguably, Greece moved to a Ponzi posture because of its fiscal effort to satisfy the Maastricht's criteria, which induced a rise in the total government revenues as a percent of GDP, as well as because of the high growth rates in the late 1990's, which permitted to the government to take advantage of the automatic stabilisers (see Appendix 2).

[Figure 1 near here]

After the adoption of the euro in 2001, the Greek government sector remained in the Ponzi finance regime only for two years, shifting to the ultra-Ponzi regime in 2003. As a result, the government debt in nominal terms increased substantially over the period 2003-2009 and so did the need for debt refinancing. The surge in debt did not initially lead to a much higher debt to GDP ratio since the growth rate of the economy remained till 2007 higher than the real interest rate (see Appendix 2). ${ }^{14}$ However, when the economy slipped into a recession in 2008 , the real growth rate became lower than the real interest rate leading to a significant rise in the government debt to GDP ratio in 2009. This rise was enhanced by the substantial increase in the budget deficit in the period 2008-2009, which is explained inter alia by the impact of automatic stabilisers, as a result of the recession. ${ }^{15}$ The increase in the budget deficit is also behind the fall in the liquidity index from -1.30 in 2007 to -1.45 in 2009 . Remarkably, this fall is also linked with the higher principal repayments over this period (see Appendix 2). The rise in the debt to GDP ratio combined with the increasing 
financing needs rendered the Greek government sector extremely vulnerable to the expectations of the sovereign bond holders and the speculation in the global financial markets.

An important message from the evolution of the liquidity index after the adoption of the euro in 2001 is that the Greek government made no effort to increase tax revenues and curtail tax evasion during a period of high growth. Government revenues remained low relative to GDP (see Appendix 2). The easiness to roll-over debt via the financial markets motivated the Greek government to rely more on new borrowing. Significant was also the effect of Greece's structural competitiveness problems on the deterioration of the liquidity index. These problems, which are reflected on its persistent trade deficit (see Appendix 2), restricted the contribution of debt-financed government expenditures to the growth of the domestic product with negative feedback effects on government revenues.

[Table 1 near here]

Table 1 displays the values of the other four indexes that capture the financial fragility of the Greek government sector. We observe the following: First, the debt maturity index increased from $29.5 \%$ in 1999 to $56.1 \%$ in 2008 . This development reflects the fact that in the years just before and after the entrance of Greece in the Eurozone government's new borrowing took place to a great extent via long-term bonds. Therefore, the adverse effects of the accumulation of debt and financial commitments were not very apparent in the short run, preventing the liquidity index to further deteriorate over the first years after the entrance in the EMU. This, however, came 
with a cost: the effects of the rising proportion of long-term debt started to materialise basically after 2007, when a significant part of this long-term debt needed to be refinanced. This rise in the principal repayment put substantial pressure on the financial position of the Greek government, since it coincided with the outbreak of the global financial crisis, which generated financial turbulence and conservative perceptions of risk by investors. In addition, the Greek economy shifted to a recessionary process in 2008 , triggering negative effects on the liquidity index. As a result, it can be ex post argued that the financial fragility of the Greek government was negatively affected by the decision made to increase long-term debt. This caused a transfer of amortisation payments from the late 1990s and early 2000s, which was a period of high growth, euphoria and financial confidence, to the period after the mid 2000s, in which there was economic contraction and collapse of confidence in the global financial markets.

Second, the liquid assets to debt ratio was very low, around to $4-5 \%$, over the period 1999-2009, which is amongst the lowest ratios in the Eurozone countries. ${ }^{16}$ This reveals that the Greek governments did not hold a sufficient amount of cash and deposits as a margin of safety against unforeseen contingencies that could potentially arise as a result of an unexpected fiscal or financial shock. Arguably, this might have been the result of the financial euphoria that Greece experienced after the country's entry into the EMU which prevented governments from paying enough attention to the creation of a sufficient amount of liquidity.

Third, the shares to debt ratio followed a downward trend over the period 1999-2009 (although with various fluctuations). In 2009 this ratio was 13.3\%, much lower than 
the average in Eurozone-17 (18.1\%). This suggests that when the debt crisis unfolded the Greek government had a relatively limited ability to use privatisations in order to cause a substantial reduction of its debt.

Fourth, the non-resident debt index gradually increased from $40.8 \%$ to $79 \%$ over the period 1999-2009. As we have already marked out, the reliance of a non-sovereign government on the international financial markets may adversely influence its financial fragility. The fact that only one fifth of debt was held domestically in 2009 reveals that the Greek government was highly dependent on the international financial markets. This was a significant reason for the Greek government sector's inability to prevent its insolvency and incredibility and to keep access to liquidity when foreign private investors' confidence about the sustainability of country's debt collapsed in 2009-2010. Besides, the accumulation of non-resident debt reduced the contribution of government's interest payments to private sector's income and thus to GDP growth.

Lastly, following the discussion in section 2 about the role of private sector's financial position in the prospects of government's financial structure, it is worthy to point out that the private credit to GDP ratio in the Greek economy climbed during the 2000s from $55.4 \%$ in 2000 to $122.6 \%$ in 2009 (see Appendix 2). This implies that the Greek economy experienced a strong increase in private credit in the pre-crisis period. This credit boom was largely associated with the entrance of the country in the Eurozone which produced a decline in the lending interest rates and facilitated the borrowing of Greek banks from the international financial markets. The credit boom enhanced 
unsustainable expenditures on consumption goods and housing. It also increased the likelihood of private sector bailouts by the government in the future.

\subsection{The after-crisis period}

The above analysis can lead us to argue that in the late 2000's the Greek public sector was susceptible to a shift in confidence due to its fragile financial structure. This shift occurred at the end of 2009 , when the country's budget deficit climbed to $15.6 \%$ of GDP. The high deficit, in conjunction with the speculative attacks on the Greek government bonds, brought about a surge in the borrowing cost for the Greek government, which became incapable of raising funds from the financial markets. As the possibility of Greece to default on its debt noticeably increased, the 'Troika', that is the International Monetary Fund (IMF), the ECB and the European Commission, moved in with an enormous bailout plan of 110 billion euros approved in May 2010, under the condition that Greece would apply an IMF-type structural adjustment programme.

In particular, the first bailout programme proposed the liberalisation of labour and product markets, the sharp reduction of government expenditures (and especially of pensions and of public sector employees' wages), the rise in tax rates and the privatisation of state enterprises. Besides, the 'Troika' claimed that wages in the private sector should be cut in order for Greece to restore its international competitiveness through an internal devaluation process. In addition, any discussion about restructuring Greece's unmanageable public debt was totally ruled out by the 'Troika' and the Greek government. 
According to the 'Troika's' claims, the neoliberal structural adjustment programme would help out Greece to place the government debt to GDP ratio on a sustainable path and to restore positive growth rates and confidence in order to return to the private capital markets in early 2012. None of these claims were verified. Instead, the economy experienced a deepening recession, ${ }^{17}$ the financial instability and the liquidity crisis were enhanced, and the government debt to GDP ratio increased much more than expected.

In Figure 1 we can see the evolution of the $L I$ during the period 2010-2011 in which Greece implemented the first adjustment programme. Three observations are in order. First, the index did not improve significantly over these two years. The Greek government remained in the ultra-Ponzi position with the index taking the values of 1.38 and -1.40 in 2010 and 2011 respectively. Despite the fact that the primary deficit was reduced from 24.2 billion euros in 2009 to 10.9 billion euros in 2010 and to 4.9 billion euros in 2011, the large amount of debt commitments prevented the index from moving closer to the Ponzi area. Second, the $L I$ decreased in 2011 relative to 2010. Despite the additional cuts that were imposed in 2011 and the larger additional decrease in the primary deficit, the index did not improve because the amortisation payments were 38.3 billion euros in 2011 instead of 30.5 billion euros in 2010. Third, if we use the projections about public revenues and primary expenditures made by the European Commission (2010) at the beginning of the programme, the value of the index should be equal to -1.35 and -1.37 in 2010 and 2011, respectively; however, Figure 1 illustrates that the actual value of the index was -1.38 and -1.40 respectively. This divergence was primarily due to the fact that the government revenues fell short of the targeted ones. In particular, in 2010 the actual value of government revenues 
was 90.2 billion euros instead of the projected value of 91.4 billion euros; and in 2011 the actual value of government revenues was 88.4 billion euros instead of the projected value of 95.3 billion euros.

Overall, the austerity measures incorporated in the first bailout plan did not have the desired effects on the liquidity of the Greek government. The underlying reason is twofold. First, the tax evasion was not significantly reduced because the Greek government failed to adequately reform the tax system in order to substantially restrict the tax evasion of self-employees and capital owners. Second, the recession in the economy and the unemployment rate were much higher than the projected ones. The recessionary effects of fiscal measures were extremely important not only because of their Keynesian impact on domestic demand but also because of the materialisation of 'anti-Ricardian effects': the expectation for more austerity and, thus, for further reduction in incomes, adversely affected private consumption and investment expenditures (see Boyer, 2012). Moreover, the cuts in private sector wages produced a higher than anticipated reduction in private consumption and the lack of structural competitiveness in the Greek economy, due to its weak and limited productive capacity, constrained the rise of exports. ${ }^{18}$ The deeper than expected recession and the higher than expected unemployment had detrimental effects on revenues and on certain government expenditures (e.g. unemployment benefits). Besides, it is important to underline that anytime there was a difference between the actual and the targeted public revenues, the 'Troika' required additional measures, entrapping the economy into a vicious cycle. 
In 2011 Greece's government debt was completely unsustainable and unmanageable. This led the 'Troika' to revise its initial decision of no debt restructuring since it was realised that without a reduction of its debt commitments the Greek government could not restore solvency. On 26/27 October 2011 the 'Troika' agreed upon a Private Sector Involvement (PSI) programme designed to reduce the privately held sovereign debt of Greece by 53.5\%. The programme materialised in March 2012. Furthermore, on 21 February 2012 a second adjustment programme for Greece was agreed. This programme was envisaged to cover the financing needs of the Greek government sector till the end of 2014. Importantly, the new financial support to Greece was conditional on the implementation of new fiscal austerity measures and the further liberalisation of the labour market. However, new financing gaps emerged during the next months, creating the need for further reduction in Greece's debt and financial commitments. On 26/27 November 2012 the Euro area members agreed upon a new set of measures designed to relieve Greece's burden of debt. These included, inter alia, a debt buyback programme, the reduction of Greek Loan Facility (GLF) interest margin, the deferral of European Financial Stability Fund (EFSF) interest payments by 10 years and the extension of the maturities of the GLF and EFSF loans by 15 years (see EFSF 2013).

In Figure 1 we observe that the $L I$ increased in 2012 relative to 2011. The PSI programme contributed to this improvement of the index. However, despite the decrease in debt commitments in 2012 and the additional cuts in primary expenditures, the index did not improve significantly. If we use the projections about government revenues and primary expenditures made by the European Commission (2010), the value of the liquidity index should be equal to -0.25 in 2012 . In contrast, 
Figure 1 illustrates that the actual value of the index was -1.34. This deviation between the expected and the actual value of the $L I$ was basically the result of the lower actual total revenues, which were equal to 86.7 billion euros, relative to the targeted ones amounted to 97.7 billion euros. ${ }^{19}$ Again, the deeper than expected recession was behind the insufficient amount of government revenues.

Some further developments need to be highlighted. First, the proportion of the Greek government debt held by non-residents increased from $73.3 \%$ in 2011 to $83.6 \%$ in 2012 (see Table 1). This was due to the involvement of Greek banks and private bondholders in the PSI programme that reduced their share in the Greek government debt, as well as due to the increase in the proportion of the Greek government debt held by the official sector (i.e. the IMF and the stability mechanisms of the EU). The rise in the non-resident debt implies a higher reliance on foreigners for the refinancing of $\mathrm{debt}^{20}$ and a greater redistribution of income from the domestic economy to the external sector. Second, the debt maturity index increased significantly in 2012, reflecting the substitution of longer-term debt for shorter-term one, as a result of the PSI programme and the other measures taken to relieve Greece's burden of debt. Although this rise in long-term debt is beneficial in the short run, it may have detrimental effects on the financial position of the Greek government in the long run. Third, the shares to debt ratio increased from $9.6 \%$ in 2011 to $21.6 \%$ in 2012 , but this was largely due to the acquisition of shares by the Greek government in the context of its support to the financial sector (see Eurostat 2013). Fourth, the credit to GDP ratio of the private sector further increased in the after-crisis period (see Appendix 2) and the rate of non-performing loans achieved a record high in 2012, revealing an extremely fragile private sector. 
Regarding the prospects of the government's financial position in the future, it can be asserted that these crucially depend on the stance of the other sectors of the economy. According to the 'financial balances approach', the targeted decline in Greece's budget deficit prerequisites the deterioration in the balance of the private and/or the foreign sector. There are, arguably, three alternative scenarios in the coming years if the current economic policy continues to be implemented without a new debt relief. The first scenario is that the private and the foreign sector will sufficiently decrease their balances basically by spending more. Under this scenario, the desired decline in the fiscal deficit can be achieved without leading to lower output. The second scenario is that these two sectors will not spend enough and the resulting decline in GDP (due to the fact that private expenditures and exports will not counter the negative impact of fiscal measures on output) will make lower the saving of the private sector and the imports of the economy, without any significant negative effect on the government revenues. In this case, the desired decline in the government budget deficit will approximately be attained (potentially with some additional austerity measures), but at the cost of a lower output, with unfavourable effects on the debt to GDP dynamics. The third scenario is the same with the second one with the only difference being that the fiscal consolidation and the deepening recession will generate, due to automatic stabilisers, lower than the expected revenues and higher than the expected expenditures, preventing the targeted fiscal deficit from being achieved.

Our argument is that the private sector is not likely to spend enough and that a substantial increase in country's exports will not occur due to Greece's structural competitiveness problems (see also Papadimitrou, Nikiforos, and Zezza 2013). It is 
also plausible that the resulting reduction in GDP will have important adverse effects on government revenues. Thus, we contend that the third scenario is the most probable one. Moreover, as long as the Greek debt continues to be considered unsustainable, the liquidity and solvency problems will be reinforced and will rapidly multiply and spread to the economy increasing financial instability. In this case, Greece will continue to evolve through a debt-deflation process with catastrophic employment, growth and wealth effects that will further reduce the government sector's ability to make lower its financial fragility and to meet its debt commitments.

\section{Conclusions}

In this paper, Minskyan financial fragility indices for the government sector have been proposed and estimated for the Greek economy. Particular attention has been paid to the cash inflows and cash outflows relationships of the government sector, as well as to balance sheet considerations. It has been indicated that the general government of Greece has been in the ultra-Ponzi finance regime since 2003. Moreover, it has been shown that certain features of the government's financial structure (the ratio of nonresident to total debt, the liquid assets to debt ratio and the shares to debt ratio) either deteriorated or did not improve in the pre-crisis period, contributing to the financial fragility of the Greek government sector.

The paper has also pinpointed that, contrary to the expectations of the 'Troika', the austerity measures incorporated in the first and the second adjustment programmes for Greece did not improve significantly the financial fragility of the Greek government sector in the after-crisis period. The implemented policy has caused a prolonged 
recession, which has systematically exerted a negative feedback impact on the government revenues undermining the government sector's capacity to attain a primary fiscal surplus. As a result, the Greek government sector has not so far shifted from the ultra-Ponzi to the Ponzi regime. In addition, the government debt to GDP ratio has not been placed on a sustainable path and no important improvement has been reported in other features of the Greek government's financial structure. Overall, our analysis disputes the effectiveness of the conducted neoliberal programmes in Greece in terms of creating the conditions for the government to meet its debt commitments, as well as in terms of restoring government sector's solvency, credibility and financial viability. 


\section{Notes}

1. The financial posture of the government sector can also be important in the case of sovereign countries, in so far as the fiscal balance affects the external balance. In particular, under fixed exchange rate regimes, fiscal deficits are likely to cause an undesirable reduction in international reserves (see Wray 2006). Under flexible exchange rate regimes, fiscal deficits can lead to domestic exchange rate depreciation, with potential detrimental effects on inflation and the ability of a country to meet its financial commitments denominated in foreign currency. Furthermore, in both regimes fiscal deficits may have adverse effects on the interest rates. However, in non-sovereign countries the risks stemming from a financially fragile government sector are, arguably, more significant and straightforward.

2. Of course, even if the ECB was authorised to operate as 'lender of last resort', this would not eliminate all risks of partial default for bond holders. In particular, both the exchange rate risk and the inflation risk would still exist. However, the main source of default risk would not be present.

3. On 6 September 2012, the ECB announced its Outright Monetary Transactions (OMT) programme. Through this programme the ECB committed to set a floor to the price of government bonds by making unlimited purchases in the secondary sovereign market. The OMT framework has substantially promoted ECB's role as 'lender of last resort' to national governments. However, it has not arguably rendered the ECB a full 'lender of last resort' to the public sector basically for two main reasons. First, the ECB continues to be prohibited to intervene in the primary bonds market. Second, a necessary condition for a country to qualify for bond purchases by the ECB is to have beforehand committed to some kind of austerity programme. The latter implies that the ECB supports the fiscal policies of Eurozone national governments only when it approves them.

4. Although Minsky's original classification relies on three finance regimes, in the case of government it seems appropriate to extend Minsky's taxonomy by introducing a fourth finance regime (the ultra-Ponzi one), which reflects the case of a government running a primary deficit. Note that Arestis and Glickman (2002) have used a four financial postures taxonomy in their analysis of an open economy's financial fragility.

5. The net debt is defined here as the difference between the market value of financial liabilities and the market value of financial assets. The gross debt does not necessarily rise in the case of Ponzi or 
ultra-Ponzi finance, as the government may, for instance, sell some financial assets in order to reduce its gross debt. Similarly, the gross debt does not necessarily decline in the case of hedge or speculative finance as the government may decide to purchase a significant amount of financial assets, offsetting the favourable effects of fiscal surplus on gross debt. For a detailed analysis of the relationship between gross debt, net debt and fiscal balance see Milesi-Ferretti and Moriyama (2006) and Hartwig Lojsch, Rodriguez-Vives, and Slavik (2011).

6. See also Minsky's ([1986] 2008, ch. 2) analysis for the budget effects of the 'Big Government'.

7. See, for instance, the theoretical and the empirical literature on the Laffer curve (e.g. Fullerton 1982; Matthews 2003; Heijman and van Ophem 2005).

8. See also Ferrari-Filho, Terra, and Conceição (2010).

9. Note that the mathematical formula used in the cases of hedge and speculative finance is the same. Moreover, the mathematical formula is almost identical in the cases of the Ponzi and the ultra-Ponzi finance: the only difference is that in the case of the ultra-Ponzi regime, -1 has been added to penalise for the existence of a primary deficit. In this way it is ensured that the index for a government that runs a primary deficit always lies between -2 and -1 . This enables a clear distinction between a Ponzi and an ultra-Ponzi regime.

10. In Ferrari-Filho, Terra, and Conceição (2010) when the index is higher than one, the government sector is hedge: total revenues are larger than the sum of total primary expenditures, interest and amortisation. If the index lies between zero and one, the government sector is speculative: the primary budget surplus is unable to cover the sum of interest and amortisation. If the index is negative, the government sector is Ponzi: the public sector runs a primary budget deficit.

11. For further discussion on this issue see Wolswijk and de Haan (2005) and Blommestein, Keskinler, and Flores (2011).

12. An additional index that could be used for the evaluation of government's financial fragility is the non-financial assets to debt ratio. In this paper such an index is not utilised because there are no available data for the non-financial assets of the Greek government sector (see Bova et al. 2013). Note, however, that the role of these assets is to some extent taken into account in our analysis: the proceeds from the sale of non-financial assets are reported in government primary expenditures as negative gross fixed capital formation (see Milesi-Ferretti and Moriyama 2006, 3287) and thus affect our liquidity index. 
13. At this point certain clarifications are necessary. Greece relinquished its monetary sovereignty in 2001, when it became a member of the Eurozone. Thus, the value of the liquidity index is more important and meaningful for the period since 2001. However, we also present data for the preEMU period for two reasons. First, this allows us to show the path dependency of the Greek government sector's financial posture, since previous regimes affect current debt commitments. Second, as pointed out in footnote 1 , the financial posture of the government sector can also be important in the case of sovereign countries. For the other financial fragility indices the analysis starts from the year 1999, i.e. the year that the European Monetary Union (EMU) was set up.

14. In Appendix 2 the real pre-tax interest rate has been used instead of the real after-tax interest rate due to the absence of available data for the tax rate on interest payments.

15. See Papadimitriou, Wray, and Nersisyan (2010).

16. The only countries that report (on average) lower liquid assets to debt ratios than Greece over this period are France, Italy and Belgium. On the contrary, Denmark, Spain, Ireland, Luxembourg, Finland and Germany turn out to hold on average above $10 \%$ of their debt in the form of currency and deposits.

17. In particular, the growth rate of GDP was $-4.9 \%,-7.1 \%$ and $-6.4 \%$ in 2010,2011 and 2012 , respectively. The unemployment rate increased from $9.5 \%$ in 2009 to $24.3 \%$ in 2012 (see Appendix 2).

18. The exports of Greece were also negatively influenced by the recession or weak economic growth in its trade partners.

19. An additional reason is the capital transfer expenditures for banks' resolution, amounted to 8.4 billion euros in 2012. The recording of these transfers is provisional and subject to revision, since the fair value of the assets of banks under liquidation has not yet been provided (see Hellenic Statistical Authority 2013). However, even if these expenditures are not taken into account the value of the liquidity index is still lower than the expected one.

20. Needless to say, since the main foreign lender of Greece is now the official and not the private sector, the reliance on non-residents for the refinancing of the Greek government debt is of different nature relative to the pre-crisis period. This reliance is now more closely related to political decisions. 


\section{References}

AMECO. 2005. List of variables. Germany: ECB.

Arestis, P., and M. Glickman. 2002. Financial crisis in Southeast Asia: Dispelling illusion the Minskyan way. Cambridge Journal of Economics 26, no. 2: 237-260.

Bank of Italy. 2011. Financial stability report November, no. 2. Italy: Bank of Italy.

Bell, S. 2003. Common currency lessons from Europe: Have member states forsaken their economic steering wheels?. In Dollarization: Lessons from Europe and the Americas, ed. L.-P. Rochon and M. Seccareccia, 70-91. UK: Routledge.

Bellofiore, R., and P. Ferri, ed. 2001. Financial Keynesianism and market instability: The economic legacy of Hyman Minsky Volume 1. UK: Edward Elgar.

Blommestein, H., A. Keskinler, and P. Flores. 2011. Highlights from the OECD sovereign borrowing outlook no. 4. OECD Journal, Financial Market Trends 2, no. 101: 1-11.

Bova, E., R. Dippelsman, K. Rideout, and A. Schaechter. 2013 Another look at governments' balance sheets: The role of nonfinancial assets. Working Paper No. 95, USA: IMF.

Boyer, R. 2012. The four fallacies of contemporary austerity policies: The lost Keynesian legacy. Cambridge Journal of Economics 36, no. 1: 283-312.

Broos, M., and J. de Haan. 2012. Government bond yields and foreign ownership of debt. Applied Economics Letters 19, no. 5: 435-438.

ECB. 2010. Monthly bulletin - Euro area statistics methodological notes, section 6 government finance. Germany: ECB.

EFSF. 2013. European financial stability facility, section H, 21 January 2013. Luxembourg: EFSF. 
European Commission. 2010. The economic adjustment programme for Greece. Occasional Papers No. 61, Belgium: European Commission.

Eurostat. 2011. Manual on sources and methods for the compilation of ESA 95 financial accounts: 2nd Edition - 2011 Update. Eurostat Methodologies and Working Papers. Belgium: European Commission.

Eurostat. 2013. Stock-flow adjustment (SFA) for the Member States, the Euro area and the EU27 for the period 2009-2012, as reported in the April 2013 EDP notification: The main factors contributing to changes in government debt other than government deficits/surpluses (stock-flow adjustment). Belgium: European Commission.

Fazzari, S., and D.B. Papadimitriou, ed. 1992. Financial conditions and macroeconomic performance: Essays in honor of Hyman P. Minsky. USA: M.E. Sharpe.

Ferrari-Filho, F., F. Terra, and O. Conceição. 2010. The financial fragility hypothesis applied to the public sector: An analysis for Brazil's economy from 2000 to 2008 . Journal of Post Keynesian Economics 33, no. 1: 151-168.

Fullerton, D. 1982. On the possibility of an inverse relationship between tax rates and government revenues. Journal of Public Economics 19, no. 1: 3-22.

Godley, W., D.B. Papadimitriou, G. Hannsgen, and G. Zezza. 2007. The U.S. economy: Is there a way out of the woods? Strategic Analysis November, USA: Levy Economics Institute of Bard College.

Hartwig Lojsch, H.D., M. Rodriguez-Vives, and M. Slavik. 2011. The size and composition of government debt in the Euro area. Occasional Paper Series No. 132, Germany: ECB. 
Heijman, W., and J. van Ophem. 2005. Willingness to pay tax: The Laffer curve revisited for 12 OECD countries. The Journal of Socio-Economics 34, no. 5: 714723.

Hellenic Republic Ministry of Finance. 2013. Public debt bulletin 69, March 2013. Greece: Ministry of Finance.

Hellenic Statistical Authority. 2013. Press release: Fiscal data for the years 20092012, April 2013. Greece: Hellenic Republic.

IMF. 2013. Greece: First and second reviews under the extended arrangement under the extended fund facility, request for waiver of applicability, modification of performance criteria, and rephasing of access. Country Report No. 20, USA: IMF.

Kelton, S., and R. Wray. 2009. Can Euroland survive?. Public Policy Brief No. 106, USA: Levy Economics Institute of Bard College.

Kregel, J. 2008. Minsky's cushions of safety: Systemic risk and the crisis in the U.S. subprime mortgage crisis. Public Policy Brief No. 93, USA: Levy Economics Institute of Bard College.

Kregel, J. 2011. Debtors' crisis or creditors' crisis? Who pays for the European sovereign and subprime mortgage losses?. Public Policy Brief No. 121, USA: Levy Economics Institute of Bard College.

Lemmen, J., and C.A. Goodhart. 1999. Credit risks and European government bond markets: A panel data econometric analysis. Eastern Economic Journal 25, no. 1: $77-107$

Matthews, K. 2003. VAT evasion and VAT avoidance: Is there a European Laffer curve for VAT?. International Review of Applied Economics 17, no. 1: 105-114.

Milesi-Ferretti, G., and K. Moriyama. 2006. Fiscal adjustment in EU countries: A balance sheet approach. Journal of Banking and Finance 30, no. 12: 3281-3298. 
Minsky, H.P. 1982. Inflation, recession and economic policy. USA: M.E. Sharpe.

Minsky, H.P. 1992. The capital development of the economy and the structure of financial institutions. Working Paper No. 72, USA: Levy Economics Institute of Bard College.

Minsky, H.P. 2008. Stabilizing an unstable economy. USA: Mc Graw Hill.

Papadimitriou, D.B., and R. Wray, ed. 2010. The Elgar companion to Hyman Minsky. USA: Edward Elgar.

Papadimitrou, D.B., M. Nikiforos, and G. Zezza. 2013. Waiting for export-led growth: Why the Troika's Greek strategy is failing. One-Pager No. 41, USA: Levy Economics Institute of Bard College.

Papadimitriou, D.B., R. Wray, and Y. Nersisyan. 2010. Endgame for the Euro? Without major restructuring, the Eurozone is doomed. Public Policy Brief No. 113, USA: Levy Economics Institute of Bard College.

Sardoni, C., and R. Wray. 2006. Monetary policy strategies of the European Central Bank and the Federal Reserve Bank of the United States. Journal of Post Keynesian Economics 28, no. 3: 451-472.

Sawyer, M. 2001. Minsky's analysis, the European single currency and the global financial system. In Financial Keynesianism and market instability: The economic legacy of Hyman Minsky Volume 1, ed. R. Bellofiore and P. Ferri, 179-193, USA: Edward Elgar.

Sawyer, M. 2011. UK fiscal policy after the global financial crisis. Contributions to Political Economy 30, no. 1: 13-29.

Semieniuk, G., T. van Treeck, and A. Truger. 2011. Reducing economic imbalances in the Euro area: Some remarks on the current stability programs, 2011-14. Working Paper No. 694, USA: Levy Economics Institute of Bard College. 
Tymoigne, E. 2009. Central banking, asset prices and financial fragility. USA: Routledge.

Wolswijk, G., and J. de Haan. 2005. Government debt management in the Euro Area: Recent theoretical developments and changes and practices. Occasional Paper Series No. 25. Germany: ECB.

Wray, R. 2003. Is Euroland the next Argentina?. Working Paper No. 23, USA: Center for Full Employment and Price Stability.

Wray, R. 2006. Extending Minsky's classifications of fragility to government and the open economy. Working Paper No. 450, USA: Levy Economics Institute of Bard College.

Wray, R. 2012. Modern money theory: A primer on macroeconomics for sovereign monetary systems. USA: Palgrave Macmillan.

Zezza, G. 2012. The impact of fiscal austerity in the Eurozone. Review of Keynesian Economics, Inaugural issue: 37-54. 
Figures and Tables

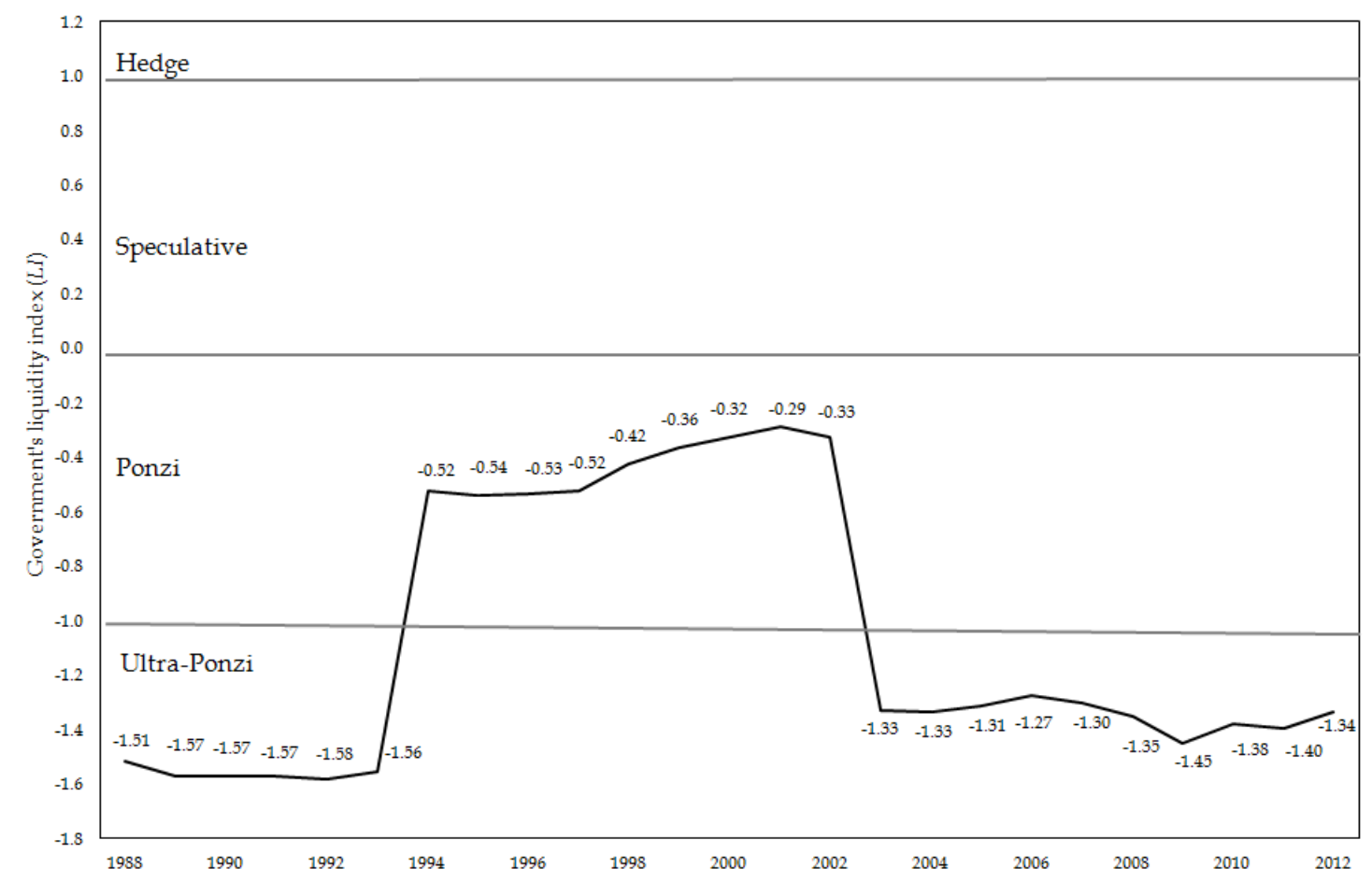

Figure 1. Government's liquidity index (LI), Greece, 1988-2012

Note: For the data sources and the definitions of the variables used to construct the index see Appendix 1. 
Table 1. Financial fragility indices, government sector, Greece, 1999-2012.

\begin{tabular}{ccccc}
\hline Year & $\begin{array}{c}\text { Debt maturity } \\
\text { index }\end{array}$ & $\begin{array}{c}\text { Liquid assets to } \\
\text { debt ratio }\end{array}$ & $\begin{array}{c}\text { Shares to debt } \\
\text { ratio }\end{array}$ & $\begin{array}{c}\text { Non-resident debt } \\
\text { index }\end{array}$ \\
\hline 1999 & 29.5 & 5.4 & 20.4 & 40.8 \\
2000 & 34.2 & 4.2 & 14.7 & 42.1 \\
2001 & 39.2 & 4.1 & 13.2 & 43.4 \\
2002 & 22.6 & 3.9 & 11.4 & 45.9 \\
2003 & 29.2 & 3.9 & 14.0 & 53.7 \\
2004 & 33.1 & 4.9 & 14.7 & 60.0 \\
2005 & 40.9 & 3.9 & 17.3 & 67.9 \\
2006 & 47.4 & 3.9 & 15.5 & 69.8 \\
2007 & 55.6 & 3.8 & 18.0 & 75.8 \\
2008 & 56.1 & 5.0 & 11.1 & 78.4 \\
2009 & 52.6 & 3.9 & 13.3 & 79.0 \\
2010 & 48.6 & 5.1 & 11.4 & 75.2 \\
2011 & 39.8 & 4.1 & 9.6 & 73.3 \\
2012 & 71.7 & 6.8 & 21.6 & 83.6 \\
\hline
\end{tabular}

Note: For the precise definitions of the indices and the data sources see Appendix 1. 


\section{Appendix 1. Definitions and data sources}

\begin{tabular}{|c|c|c|}
\hline Variable/ Index & Definition & Data source \\
\hline Total government revenues $(T R)$ & $\begin{array}{l}\text { Sales of market output and output- for own final use }+ \\
\text { payments for other non-market output }+ \text { other } \\
\text { subsidies on production, receivable }+ \text { taxes on } \\
\text { production and imports, receivable }+ \text { property } \\
\text { income, receivable }+ \text { current taxes on income and } \\
\text { wealth, receivable }+ \text { social contributions, receivable } \\
+ \text { other current transfers, receivable }+ \text { capital } \\
\text { transfers, receivable. }^{1} \text { The data refer to the general } \\
\text { government. }\end{array}$ & $\begin{array}{l}\text { AMECO database } \\
\text { (code: URTG) }\end{array}$ \\
\hline $\begin{array}{l}\text { Total primary government } \\
\text { expenditures }(T E)\end{array}$ & 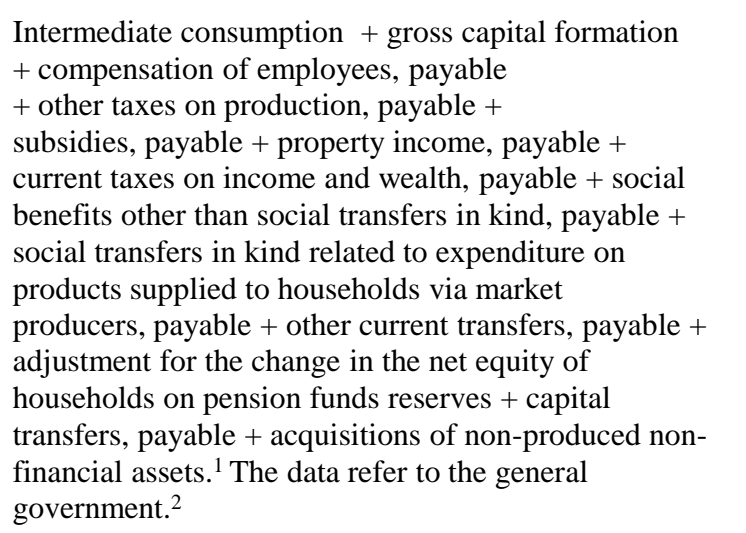 & $\begin{array}{l}\text { AMECO database } \\
\text { (code: UUTGI) }\end{array}$ \\
\hline Interest payments $(I N T)$ & Interest paid by the general government ${ }^{2}(\mathrm{EDP})$. & $\begin{array}{l}\text { AMECO database } \\
\text { (code: UYIGE) }\end{array}$ \\
\hline Amortisation $(A M O R T)$ & $\begin{array}{l}\text { Amortisation of the medium- and long-term debt of the } \\
\text { central government and social security funds }+ \text { short- } \\
\text { term debt of the central government at the end of the } \\
\text { previous period. }\end{array}$ & $\begin{array}{l}\text { Hellenic Republic } \\
\text { Ministry of Finance and } \\
\text { Bank of Greece }^{4}\end{array}$ \\
\hline Gross domestic product (GDP) & Gross domestic product at current market prices. & $\begin{array}{l}\text { AMECO database } \\
\text { (code: UVGD) }\end{array}$ \\
\hline Debt maturity index & $\begin{array}{l}\text { The ratio of general government }{ }^{2} \text { debt with residual } \\
\text { maturity more than five years to total general } \\
\text { government debt (EDP), in percent }(\%) .^{5}\end{array}$ & $\begin{array}{l}\text { ECB database, } \\
\text { government debt }^{6}\end{array}$ \\
\hline Liquid assets to debt ratio & $\begin{array}{l}\text { The ratio of currency and deposits (asset side) to general } \\
\text { government }{ }^{2} \text { debt (EDP), in percent }(\%) .^{7}\end{array}$ & $\begin{array}{l}\text { Eurostat, economy and } \\
\text { finance, European sector } \\
\text { accounts }\end{array}$ \\
\hline Shares to debt ratio & $\begin{array}{l}\text { The ratio of shares and other equity (asset side) to } \\
\text { general government }{ }^{2} \text { debt (EDP), in percent }(\%){ }^{8}\end{array}$ & $\begin{array}{l}\text { Eurostat, economy and } \\
\text { finance, European sector } \\
\text { accounts }\end{array}$ \\
\hline Non-resident debt index & $\begin{array}{l}\text { The ratio of non-resident debt to general government }{ }^{2} \\
\text { debt (EDP), in percent }(\%) .{ }^{9}\end{array}$ & $\begin{array}{l}\text { ECB database, } \\
\text { government debt }\end{array}$ \\
\hline Real interest rate & $\begin{array}{l}\text { The real long-term interest rate (based on the GDP } \\
\text { deflator), in percent }(\%) \text {. The data refer to the central } \\
\text { government. }\end{array}$ & $\begin{array}{l}\text { AMECO database } \\
\text { (code: ILRV) }\end{array}$ \\
\hline Real growth rate & $\begin{array}{l}\text { The growth rate of gross domestic product at constant } \\
\text { (2005) market prices, in percent }(\%) \text {. }\end{array}$ & $\begin{array}{l}\text { AMECO database } \\
\text { (code: OVGD) }\end{array}$ \\
\hline
\end{tabular}


(continued from the previous page)

Government debt to GDP ratio

Unemployment rate

Credit to GDP ratio

Trade balance of goods and services, in percent $(\%)$ of GDP
The gross general government ${ }^{2}$ debt (EDP), in percent (\%) of GDP.

Unemployed persons as a percentage (\%) of the total active population (labour force).

Ratio of non-financial private debt to gross domestic product at market prices, in percent $(\%)$.

The difference between export of goods and services and imports of goods and services, in percent (\%) of GDP.
AMECO database (code: UDGGL)

AMECO database (code: ZUTN)

ECB database, Euro area accounts, main indicators

AMECO database (code: UBGS)

\section{Notes:}

1/ For a description of these variables see AMECO (2005).

2/ The general government in Greece comprises the central government, the social security funds and the local government.

3/ There are no available data for the amortisation payments of the local government.

4/ The figures for 2012 are taken from IMF (2013).

5/ See ECB (2010) for the definition of residual maturity.

6/ The figure for 2012 is taken from the Hellenic Republic Ministry of Finance (2013) and refers to central government debt.

7/ See Eurostat (2011) for the definition of currency and deposits.

8/ See Eurostat (2011) for the definition of shares and other equity.

9/ See ECB (2010) for the definition of non-resident debt. 
Appendix 2. Fiscal and macroeconomic variables, Greece, 1988-2012

\begin{tabular}{|c|c|c|c|c|c|c|c|c|c|c|}
\hline Year & $\begin{array}{c}\text { Total } \\
\text { government } \\
\text { revenues, in } \\
\text { percent }(\%) \\
\text { of GDP }\end{array}$ & $\begin{array}{c}\text { Total government } \\
\text { primary } \\
\text { expenditures, in } \\
\text { percent }(\%) \text { of } \\
\text { GDP }\end{array}$ & $\begin{array}{c}\text { Interest } \\
\text { payments, in } \\
\text { percent }(\%) \\
\text { of GDP }\end{array}$ & $\begin{array}{c}\text { Amortisation, } \\
\text { in percent }(\%) \\
\text { of GDP }\end{array}$ & $\begin{array}{l}\text { Real pre-tax } \\
\text { interest } \\
\text { rate, in } \\
\text { percent }(\%)\end{array}$ & $\begin{array}{l}\text { Real growth } \\
\text { rate, in } \\
\text { percent }(\%)\end{array}$ & $\begin{array}{l}\text { Government } \\
\text { debt to GDP } \\
\text { ratio, in } \\
\text { percent }(\%)\end{array}$ & $\begin{array}{c}\text { Unemployment } \\
\text { rate, in percent } \\
(\%)\end{array}$ & $\begin{array}{l}\text { Credit to } \\
\text { GDP } \\
\text { ratio, in } \\
\text { percent } \\
(\%)\end{array}$ & $\begin{array}{c}\text { Trade balance of } \\
\text { goods and } \\
\text { services, in } \\
\text { percent }(\%) \text { of } \\
\text { GDP }\end{array}$ \\
\hline 1988 & 29.2 & 33.0 & 6.6 & 20.5 & $\overline{-0.1}$ & 4.3 & 61.6 & 6.8 & $\overline{\mathrm{NA}}$ & -5.1 \\
\hline 1989 & 28.6 & 34.1 & 6.7 & 25.9 & NA & 3.8 & 64.8 & 6.7 & NA & -7.1 \\
\hline 1990 & 31.0 & 36.2 & 9.0 & 26.9 & NA & 0.0 & 71.7 & 6.4 & NA & -8.8 \\
\hline 1991 & 32.1 & 33.4 & 8.7 & 32.9 & NA & 3.1 & 74.0 & 7.1 & NA & -8.5 \\
\hline 1992 & 33.5 & 34.2 & 10.4 & 35.0 & 8.1 & 0.7 & 79.1 & 7.9 & NA & -7.3 \\
\hline 1993 & 34.8 & 35.5 & 11.4 & 31.4 & 7.7 & -1.6 & 99.2 & 8.6 & NA & -7.3 \\
\hline 1994 & 36.6 & 32.4 & 12.5 & 31.4 & 8.6 & 2.0 & 97.2 & 8.9 & NA & -5.6 \\
\hline 1995 & 37.0 & 34.8 & 11.3 & 34.4 & 6.5 & 2.1 & 97.9 & 9.2 & NA & -6.6 \\
\hline 1996 & 37.8 & 33.9 & 10.6 & 36.7 & 6.6 & 2.4 & 100.3 & 9.6 & NA & -7.2 \\
\hline 1997 & 39.3 & 35.9 & 9.4 & 37.4 & 2.9 & 3.6 & 97.5 & 9.8 & NA & -6.6 \\
\hline 1998 & 40.9 & 36.5 & 8.2 & 25.9 & 3.1 & 3.4 & 95.4 & 11.1 & NA & -7.5 \\
\hline 1999 & 41.8 & 37.4 & 7.4 & 20.6 & 3.2 & 3.4 & 94.9 & 12.0 & NA & -7.7 \\
\hline 2000 & 43.4 & 39.7 & 7.4 & 17.0 & 2.6 & 4.5 & 104.4 & 11.2 & 55.4 & -13.6 \\
\hline 2001 & 41.3 & 39.3 & 6.5 & 12.2 & 2.1 & 4.2 & 104.7 & 10.7 & 63.0 & -13.3 \\
\hline 2002 & 40.6 & 39.9 & 5.6 & 14.9 & 1.7 & 3.4 & 102.6 & 10.3 & 67.2 & -13.7 \\
\hline 2003 & 39.4 & 40.1 & 5.0 & 13.6 & 0.3 & 5.9 & 98.3 & 9.7 & 71.2 & -12.4 \\
\hline 2004 & 38.4 & 41.0 & 5.0 & 11.6 & 1.3 & 4.4 & 99.8 & 10.5 & 77.8 & -10.1 \\
\hline 2005 & 39.0 & 39.9 & 4.5 & 12.3 & 0.8 & 2.3 & 101.2 & 9.9 & 89.3 & -9.3 \\
\hline 2006 & 39.2 & 40.6 & 4.4 & 8.9 & 1.6 & 5.5 & 107.5 & 8.9 & 97.4 & -11.4 \\
\hline 2007 & 40.7 & 42.7 & 4.5 & 11.0 & 1.1 & 3.5 & 107.2 & 8.3 & 106.6 & -14.1 \\
\hline 2008 & 40.7 & 45.5 & 5.0 & 12.1 & 0.1 & -0.2 & 112.9 & 7.7 & 118.4 & -14.5 \\
\hline 2009 & 38.3 & 48.8 & 5.2 & 15.5 & 2.8 & -3.1 & 129.7 & 9.5 & 122.6 & -11.5 \\
\hline 2010 & 40.6 & 45.5 & 5.8 & 13.7 & 7.9 & -4.9 & 148.3 & 12.6 & 127.6 & -9.3 \\
\hline 2011 & 42.4 & 44.8 & 7.1 & 18.4 & 14.5 & -7.1 & 170.3 & 17.7 & 129.1 & -8.1 \\
\hline 2012 & 44.7 & 49.7 & 5.0 & 12.6 & 23.5 & -6.4 & 156.9 & 24.3 & 129.2 & -5.0 \\
\hline
\end{tabular}

Note: For the data sources and the definitions of the variables see Appendix 1; NA: Not Available 